\title{
Over 50 years of fish community monitoring in Illinois' large rivers: The evolution of methods used by the Illinois Natural History Survey's Long-term Survey and Assessment of Large-River Fishes in Illinois
}

\author{
Mark W. Fritts, Jason A. DeBoer, \\ Daniel K. Gibson-Reinemer, Benjamin J. Lubinski, \\ Michael A. McClelland, and Andrew F. Casper
}


Prairie Research Institute

Illinois Natural History Survey

Forbes Natural History Building

1816 South Oak Street

Champaign, Illinois 61820

217-333-6880

Citation:

Fritts, M.W., J.A. DeBoer, D.K. Gibson-Reinemer, B.J. Lubinski, M.A. McClelland, and A.F.

Casper. 2017. Over 50 years of fish community monitoring in Illinois' large rivers: The evolution of methods used by the Illinois Natural History Survey's Long-term Survey and Assessment of LargeRiver Fishes in Illinois. Illinois Natural History Survey. Bulletin 41(1):1-18

For permissions: contact the Prairie Research Institute.

Editor: Lisa Sheppard

US ISSN 0073-4918

US ISBN 1-882932-38-2

(C) 2017 University of Illinois Board of Trustees. All rights reserved.

The University of Illinois will not engage in discrimination or harassment against any person because of race, color, religion, national origin, ancestry, age, marital status, disability, sexual orientation including gender identity, unfavorable discharge from the military or status as a protected veteran and will comply with all federal and state nondiscrimination, equal opportunity and affirmative action laws, orders and regulations. This nondiscrimination policy applies to admissions, employment, access to and treatment in University programs and activities.

University complaint and grievance procedures provide employees and students with the means for the resolution of complaints that allege a violation of this Statement. Inquiries or complaints may be addressed to the Director and Assistant Chancellor, Office of Equal Opportunity and Access, 601 East John Street, Swanlund Administration Building, (217) 333-0885, fax (217) 244-9136, TTY (217) 244-9850 or the Associate Provost and Director, Academic Human Resources, Henry Administration Building, (217) 333-6747, fax (217) 2445584. For other University of Illinois information, contact University Directory Assistance at 333-1000. 


\title{
Over 50 years of fish community monitoring in Illinois' large rivers: The evolution of methods used by the Illinois Natural History Survey's Long-term Survey and Assessment of Large-River Fishes in Illinois
}

\author{
Mark W. Fritts, Jason A. DeBoer, \\ Daniel K. Gibson-Reinemer, Benjamin J. Lubinski, \\ Michael A. McClelland, and Andrew F. Casper
}




\section{CONTENTS}

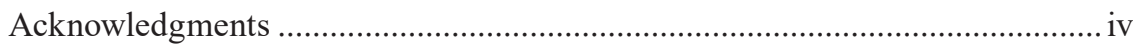

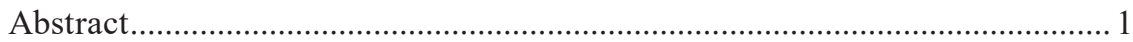

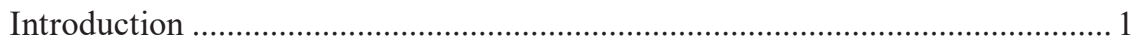

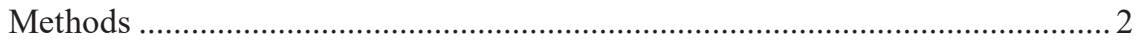

The original survey: AC electrofishing at fixed locations in the Illinois

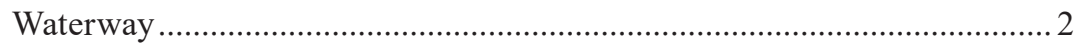

Modern, expanded components of the LTEF program ............................... 6

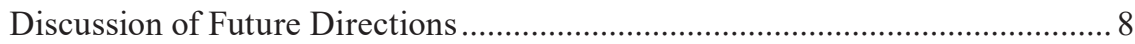

Maintenance of a fixed-site survey in a dynamic, degraded river system.... 8

A transition in electrofishing sampling approaches................................. 10

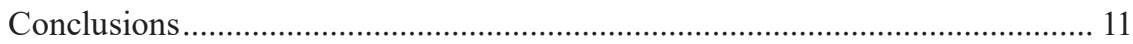

Major Contributions of the LTEF Program .................................................... 11

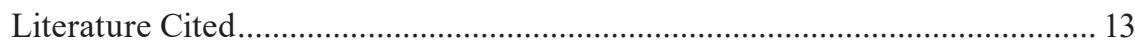

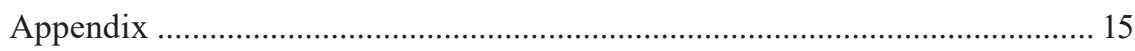




\section{ACKNOWLEDGMENTS}

We thank Jim Lamer, Rich Pendleton, and Jeff Levengood for helpful reviews of earlier versions of this manuscript. Funding for this manuscript was provided by the Federal Aid in Sport Fish Restoration Act (F-101-R), with funds administered by the U.S. Fish and Wildlife Service and the Illinois Department of Natural Resources. 


\begin{abstract}
This document describes the methodological evolution of the Long-Term Illinois Rivers Fish Population Monitoring Program since its inception. The principal changes include a shift from fixed-site sampling to stratified random sampling at the reach scale to benefit statistical robustness and a concurrent shift from AC electrofishing to pulsed-DC electrofishing to increase the breadth of the diversity and size classes of fishes encountered. These changes in methodology were implemented during the 2016 field season and are based on quantitative assessments of program data and other results from recent peer-reviewed publications. These refinements will likely improve the program's ability to detect and describe patterns and trends in the fish assemblages of the Illinois River and other large rivers of Illinois and the Midwest.
\end{abstract}

\section{INTRODUCTION}

Researchers from the Illinois Natural History Survey (INHS) have been conducting studies of fishes in Illinois' rivers and connected floodplains for nearly 140 years (Burr and Page 2009). Illinois' river and floodplain networks supported economically important commercial and recreational fisheries which declined steadily during the $20^{\text {th }}$ century as overfishing, pollution, sedimentation, the construction of dams and levees, and the subsequent alteration of riverine habitats began to affect the survival and reproductive success of fishes in these watersheds (Starrett 1971). The early reports of INHS founder Stephen A. Forbes, Charles. A. Kofoid, and Robert E. Richardson provided first-hand descriptions of the toxic, devastating effects of pollution on fish and mussel populations in the early $20^{\text {th }}$ century. The most important problem was the opening of the Chicago Ship and Sanitary Canal and the subsequent discharge of Chicago-area wastewater into the lower Illinois Waterway (Forbes and Richardson 1913). Other researchers in the INHS and the Illinois Department of Natural Resources (or its previous titles/designations) have conducted additional surveys of riverine fishes since the 1940s. However, the first and most extensive standardized survey of fishes in the Illinois River was established in 1959* by Dr. William C. Starrett, INHS Biologist and Director of the Havana Field Laboratory (Sparks and Starrett 1975). Starrett's survey focused on consistent annual sampling of fixed locations, chosen for their high-quality habitats compared with those in the rest of the river, based on his experience (R.E. Sparks, personal communication). This initial effort was meant to track changes in the system over a period of years, and became known as the Long-Term Electrofishing (LTEF) program. The program has persisted through the determined efforts of INHS biologists, despite the turnover in program leadership over time, periodic funding changes and losses, and the challenges of working in a dynamic riverine ecosystem (e.g., sedimentation, floods, and droughts).

Since 1959, the LTEF has operated an alternating current (AC) electrofishing survey at 27 fixed sampling sites throughout the Illinois Waterway, and 1 fixed site on the Mississippi River below the confluence with the Illinois River. Sampling methods, protocols, and equipment design have remained strictly standardized to maintain a greater consistency within the dataset throughout time. Because of this consistency, the LTEF is one of the premier sources of riverine fish community

\footnotetext{
* We used 1959 to denote the beginning of the LTEF program in accordance with Sparks and Starrett (1975). Limited pilot data were collected in 1957 and are included in the program's database. However, sampling was not conducted in 1958. Continuous annual monitoring began in 1959.
} 
evaluations in the country. Sampling has been conducted annually with the exception of nine years $(1958,1971,1972,1980,1981,1986$, 1987, 1988, and 1993) when extensive flooding or lack of funding precluded sampling.

The LTEF has provided a wealth of information on Illinois River fisheries for scientists, managers, and the public, and is one of the longest sustained large-river fish surveys in the world. At the program's inception, the upper reaches of the Illinois River were highly degraded by wastewater discharge from the Chicago metropolitan area. These unfavorable habitat conditions fostered a fish community dominated by invasive Common Carp (Cyprinus carpio) and Goldfish (Carassius auratus). A resurgence of the native fish community in the Illinois River following the passage and implementation of the Clean Water Act of 1972 is reflected in the recent analyses of LTEF data (McClelland et al. 2012). The Illinois River now supports a diverse native fish community, and historically documented species are once again being collected annually. The LTEF program has also been instrumental in documenting the "leading edge" of invasive species' range expansions between Lake Michigan and the Mississippi River Basin, and has provided information for monumental management efforts to control these species (Raibley et al. 1995; Irons et al. 2006, 2007, 2011; Sass et al. 2010; Liss et al. 2013, 2014; Lamer et al. 2014).

During 2009, the LTEF program expanded fisheries monitoring and research efforts on the Illinois River and portions of the Mississippi River. During 2010, the program expanded again to include fisheries monitoring on the Illinois portions of the Ohio and Wabash Rivers. However, the expanded fisheries monitoring differs from the historic $\mathrm{AC}$ electrofishing protocol by using pulsed-direct current (pulsed-DC) electrofishing protocols, similar to that used by the Upper Mississippi River Restoration Program's Long-Term Resource Monitoring (LTRM) element on the Upper Mississippi River System. Incorporating the pulsed-DC protocol allows for more statistically robust comparability over broad spatial scales (the LTRM protocol is used by five states) than the original fixed-site approach (Ratcliff et al. 2014).

The primary objective of the LTEF program has been to establish a consistent, long-term fish monitoring protocol to better understand the Illinois River fish community. This program could then be used to inform management decisions to improve the fish community and potentially restore historic ecosystem structure and function. The goals of the LTEF can be generalized to

1) determine spatial and temporal trends in fish populations of the Illinois River,

2) develop a long-term fisheries database to evaluate management strategies, and

3) provide information required to manage fisheries in Illinois' large rivers.

In pursuing these broadly defined goals, biologists of the LTEF program have used project data to document important changes in riverine fish communities and have disseminated this information through a plethora of presentations at professional conferences, technical reports and memoranda, and peer-reviewed publications and book chapters.

The purpose of this INHS Bulletin is to review the structural and methodological changes that have occurred in the LTEF program since Sparks and Starrett published their first description of the program (Sparks and Starrett 1975). This will provide a valuable and readily accessible reference for researchers to understand the development of a long-term ecological monitoring program that has greatly contributed to the collective understanding of Illinois' riverine fishes.

\section{METHODS}

\section{The original survey: $\mathrm{AC}$ electrofishing at fixed locations in the Illinois Waterway}

Standardized AC electrofishing was conducted at fixed sites in areas permanently connected, even during low river stages, to the 
main channel of the Illinois Waterway and Mississippi River (Figure 1). Sampling was conducted in six navigation reaches of the Illinois Waterway (Dresden, Marseilles, Starved Rock, Peoria, La Grange, and Alton) and one reach of the Mississippi River (Pool 26). Of the 28 sites, 2 were located on the Des Plaines River of the Illinois Waterway, 25 were on the Illinois River, and 1 was on Pool 26 of the Mississippi River. Most of these sampling stations were selected by Starrett based on his personal knowledge of fish habitats in the Illinois River (R. E. Sparks, personal communication). Collection efforts concentrated on habitats with structures, such as brush piles, stumps, undercut banks, riprap, pilings, and boat docks. However, the program's founders also selected a number of controls (i.e., sites where there is little or no structure) to test for the effects of structures on fish distribution and abundance (Sparks and Starrett 1975). Sampling was initiated at most sites (25) from 1959 to 1962, although three sites were added after Starrett's death in 1971 (Sparks and Starrett 1975).

Maintaining and replicating Starrett's established methods have been priorities of the AC electrofishing program. These have facilitated robust comparisons of catch per unit effort (CPUE) data collected over the years and have minimized the effect of sampling bias associated with changes in equipment or technique. The sampling regime consisted of a driver and single dip-netter using a boatmounted, 3-phase, 3-kw, 230-V AC generator with power transmitted from the generator to the water via a three-cable (electrode) system (Figure 2; Sparks and Starrett 1975). Electrodes were insulated by fiberglass poles (booms) and extended from the boom ends approximately 20 inches $(0.5 \mathrm{~m})$ below the water's surface, thereby creating the electric field. The sampling effort was standardized by time (normally 60 minutes of electrofishing) rather than distance at each site, which provided sampling crews the flexibility to sample unique habitat features (e.g., large woody debris, midstream rock piles, etc.) that may be under-sampled in a survey standardized by shoreline distance. Prior to beginning an electrofishing collection, the crew viewed the site to develop a sampling plan. Electrofishing was conducted upstream to downstream such that immobilized fishes were surfacing and drifting with the boat instead of drifting downstream away from it. The ideal depth for maximum sampling efficiency was approximately 3 feet $(1 \mathrm{~m})$. The structure was fished until fishes stopped surfacing, at which point the driver proceeded downstream. Fiberglass-handled dip nets with 10 foot long poles $(3.3 \mathrm{~m})$ and $1 / 4$ inch mesh netting $(6 \mathrm{~mm})$ were used to capture fishes. Captured fishes were placed in a livewell until identified to species, and then weighed and measured (Neumann et al. 2012).

Sampling occurred during a six-week period from the last week in August (beginning approximately August 24) through the first week in October (approximately October 7). This period was selected to ensure collections were made in accordance with three general criteria. First, sampling was initiated in late summer to allow young-of-year fishes (e.g., Largemouth Bass Micropterus salmoides) to grow large enough to be effectively collected. Second, sampling was conducted with a standard water temperature $\left(>58.0^{\circ} \mathrm{F}\right.$, $14.4^{\circ} \mathrm{C}$ ), reducing the likelihood of changes in fish distribution (i.e., from summer habitat to over-winter habitat) as water temperature decreases, usually during the second or third week of October. Third, sampling was conducted such that the river was no more than 2.5 feet above flat pool at stations above Starved Rock dam, no more than 1.5 feet $(0.46 \mathrm{~m})$ above "flat pool" at stations below Starved Rock dam, and rising less than 6 feet $(15 \mathrm{~cm})$ per 24 hours. These criteria reduced the dispersal or "dilution" of fishes during high river stages and ensured fishes were more concentrated in permanent and side channels. Although the rigorous standardization of sampling locations has yielded valuable information on long-term changes in fish community structure, there are also significant challenges 


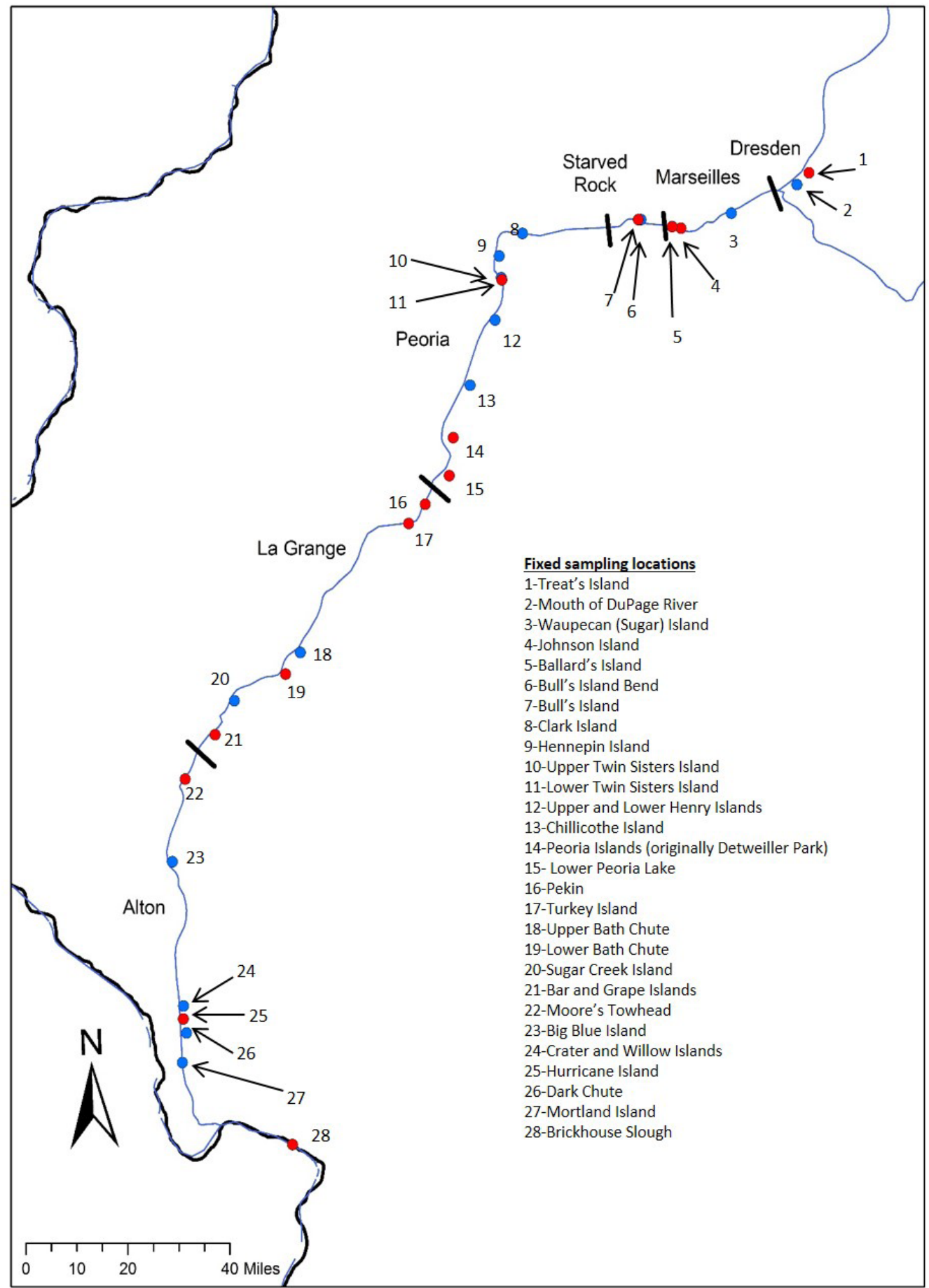

Figure 1. Map of the Illinois Waterway and the fixed locations sampled by the Long-Term Electrofishing Program using AC electrofishing gear, 1959-2015. Site locations denoted by red dots indicate sites that have been severely degraded by sedimentation or island erosion circa 2015 . 

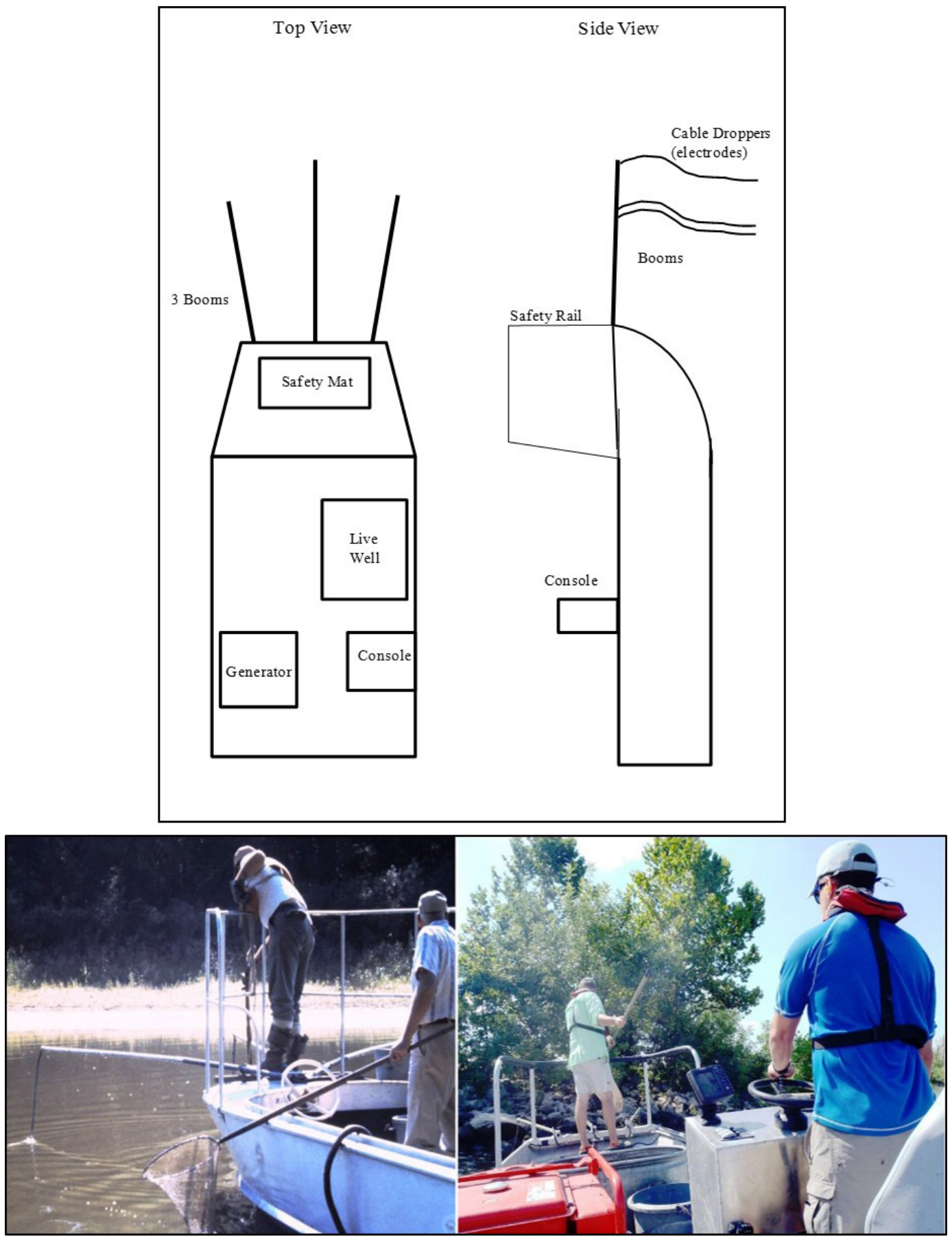

Figure 2. Diagram and photos of boat-mounted alternating current (AC) electrofishing gear used by biologists with the Illinois Natural History Survey in fixed-site fisheries surveys in the Illinois Waterway, 1959-present. Left photo: 1963, right photo: 2013. 
and concerns associated with the maintenance of a fixed-site riverine monitoring program. One potential issue is the physical change resulting from decades of increased sedimentation throughout the Illinois River Valley (Havera and Bellrose 1984). Sedimentation has led to the degradation of some sites, as well as making others inaccessible to the LTEFstandardized AC gear (Figure 1). Another issue is the natural geomorphological shift (e.g., erosion and deposition, channel meandering) common in floodplain rivers, which often occurs over decades. Although these habitat shifts would be inconsequential for short-term studies, they have the potential to substantially affect long-term studies. Specifically, habitat shifts could make it difficult to distinguish fish assemblage changes caused by natural geomorphic processes from those caused by other factors (e.g., improvements in water quality).

\section{Modern, expanded components of the LTEF program}

To complement the existing LTEF protocol, a stratified-random sampling design using pulsed-DC electrofishing was established in the Illinois Waterway during 2009. The methods for this additional sampling were adapted from the pulsed-DC sampling procedures used by the U.S. Army Corps of Engineers' Upper Mississippi River Restoration Program's LTRM element (Gutreuter et al. 1995; Ratcliff et al. 2014). Elements of the LTRM have been sampling in Pool 26 of the Mississippi River and the La Grange Reach of the Illinois Waterway since 1989 (Figure 3). The original goal of the LTEF program expansion was to provide standardized LTRM data on Illinois' large rivers where no LTRM monitoring components existed. The pulsed-DC protocols were also expanded into additional sections of the Mississippi River during 2009, and the Ohio and Wabash Rivers during 2010. In LTEF surveys, standardized pulsed-DC electrofishing is conducted at randomly selected sites only along the main channel border of the navigable sections of the rivers. Pulsed-DC electrofishing is conducted in five navigational reaches of the Illinois Waterway (Dresden, Marseilles, Starved Rock, Peoria, and Alton), eight reaches of the Mississippi River (Pools 16-21, Pool 25, and the open river below Lock \& Dam 26), four reaches of the Ohio River (Smithland Pool, Pool 52, Pool 53, and the Ohio confluence reach), and Illinois' boundary portion of the Wabash River (Figure 3). The LTEF sampling area of the open river reach of the Mississippi River spans approximately 83 river miles $(133.6 \mathrm{~km})$ and is divided into two sample segments, the Chain of Rocks Reach (river miles 165-200) and the Kaskaskia River confluence Reach (river miles 117-165).

The sampling time frame is consistent with the three LTRM sampling periods. Period I occurs June 15 to July 31, Period II occurs August 1 to September 15, and Period III occurs September 16 to October 31. An equal number of sites is allocated for each sample reach per period. Sites are generated randomly using a geographic information system (GIS) database, approximately one site per five river miles (RM) or 8.1 river kilometers (RKM). To accommodate for some of the difficulties presented by sampling in rivers with unnavigable or otherwise inaccessible areas (e.g., barge mooring areas blocking the shoreline), a subset of secondary sampling sites is generated and used as an alternate for primary sites.

Pulsed-DC electrofishing consists of a threeperson crew: a driver and two dip netters using a boat-mounted 5-kw (or greater) AC generator. Power is transmitted from the generator to the water from two booms, each constructed with a stainless steel circular ring with four stainless steel droppers attached to each ring (Figure 4). Electrodes run through the booms and attach to the rings, producing an electrical current transferred to the water from the four droppers attached to the rings. Boats are equipped with an MBS-1D (or comparable) boat electrofishing pulsed-DC control box (ETS Electrofishing, LLC) capable of delivering 4.8 kilowatts $(\mathrm{kw})$ from the generator to 


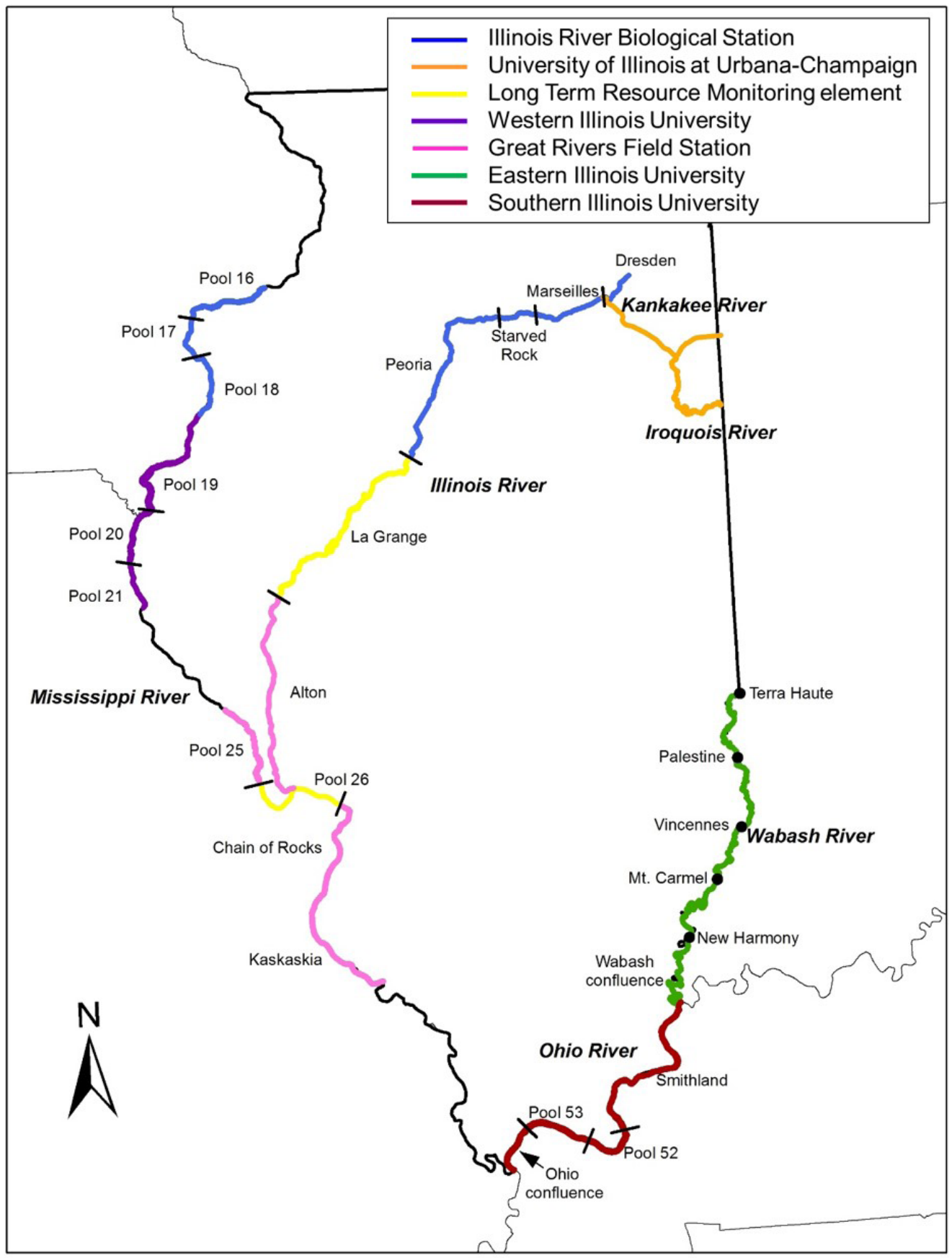

Figure 3. Map of the Illinois rivers that are sampled by various collaborators of the LTEF program (circa 2015). 
the electrodes. Pulse frequency is set to $60 \mathrm{~Hz}$ and duty-cycle is set to $25 \%$ on the control box, consistent with LTRM guidelines. Prior to beginning an electrofishing run, the control box is used to adjust voltage and amperage to a base power goal of $3 \mathrm{kw}$. The power goal is derived from water conductivity $(\mu \mathrm{S} /$ $\mathrm{cm}$ ) and water temperature at each site (Burkhardt and Gutreuter 1995). Sampling effort is standardized by time ( 15 minutes of electrofishing) and approximate distance (650 feet, approximately $200 \mathrm{~m}$ ) at each site. Collections are made with thorough coverage of fish habitat and structure, such as brush piles, stumps, undercut banks, riprap, pilings, and even boat docks within each site. Sites with little or no structure are thoroughly sampled as well. Fiberglass-handled dip nets with 8 foot long poles $(2.4 \mathrm{~m})$ and 12 inch deep $(30 \mathrm{~cm}), 1 / 8$ inch mesh $(3 \mathrm{~mm})$ netting are used to capture fishes. Captured fishes are placed in a livewell, identified to species, weighed (g) using a digital scale, and measured (total length $\mathrm{mm}$ ) (Neumann et al. 2012).

\section{DISCUSSION OF FUTURE DIRECTIONS}

\section{Maintenance of a fixed-site survey in a dynamic, degraded river system}

Biologists participating in the fixedsite, AC monitoring program have contributed to a regional understanding of the temporal and spatial differences in Illinois Waterway fish communities (e.g., Pegg and McClelland 2004; McClelland et al. 2006, 2012; Parker et al. 2015). However, the survey in its historic form is not the most efficient way to achieve ongoing program goals while adapting to changing river conditions. Benefits include a high degree of confidence that changes in the assemblage (e.g., species loss or gain) or population characteristics (e.g., size/age structure or condition indices) measured at any given site reflect actual corresponding changes in the biotic or abiotic conditions at that site. However, the greatest challenge to maintaining the fixed-site survey

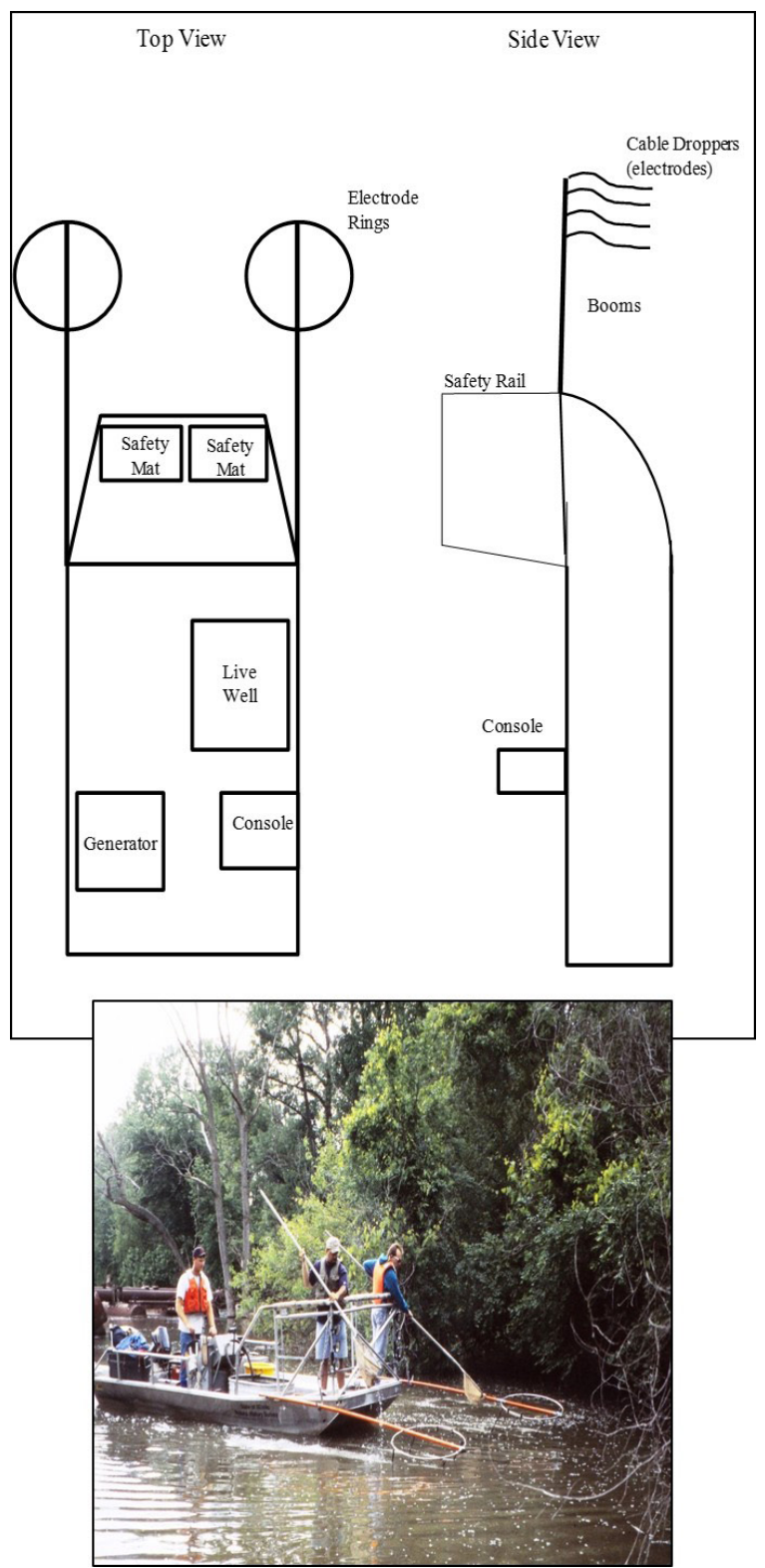

Figure 4. Diagram and photo of boat-mounted pulseddirect current (DC) electrofishing gear used by biologists with the Illinois Natural History Survey in stratifiedrandom site fisheries surveys in the Illinois, Mississippi, Ohio, and Wabash Rivers, 2009-present. 
has been the degradation/loss of fixed sampling sites because of sedimentation. Excessive sedimentation in backwater and side channel habitats has been well documented in the Illinois Waterway (Bhowmik and Demissie 1989), and over half of the original sampling locations selected by Starrett for their "good" habitat characteristics have become unnavigable or have been highly altered by erosion and the accumulation of sediments as of 2015. One notable example of the challenges that sedimentation has on maintaining fixed sampling stations is the continual degradation of a complex of sampling sites in Upper Peoria Lake. In his original survey design, Starrett established a sampling location near Detweiller Park, north of Peoria, Illinois. By 1990, the location became unnavigable and the fixed sampling location was relocated to Lambie's Boat Harbor, a small creek on the opposite shore of the lake (R.E. Sparks, unpublished data). However, Lambie's Boat Harbor became unnavigable by 2013 , and an alternate site was established downstream at the U.S. Army Corps of Engineers' Peoria Islands complex near the U.S. Highway 150 overpass (DeBoer et al. 2015), which itself became unnavigable by 2015 . Although this is an extreme example, other fixed sampling locations along the Illinois Waterway have become increasingly difficult to sample during a similar period (Figure 1). Additionally, some sampling locations around river islands have been altered by erosion and the deposition of sediments in side channels. This island erosion has changed the spatial dimensions of the islands and altered the way that water flows around the structure (e.g., Johnson Island in the Marseilles Reach, RM 249.6, and Turkey Island in the La Grange Reach, RM 148.0). These sites have changed dramatically since the beginning of the LTEF program, and thus complicate the interpretation of long-term ( $>20$ years) analysis of LTEF datasets by violating Starrett's original assumption that fixed sampling sites could control for long-term location bias.
The close proximity of some stations is another concern in maintaining the historical fixed-site design. For instance, the two stations located in the Starved Rock Reach, Bull's Island Bend (RM 241.5), and Bull's Island (RM 240.8) are directly adjacent to one another. Similarly, the Upper and Lower Twin Sisters Islands stations in the Peoria Reach (RM 203.3 and 202.8) are located on opposite shores of the river channel. The close proximity of these sampling sites could represent another source of spatial bias by limiting the spatial extent of monitoring locations in the watershed and the unintentional representation of unique communities.

McClelland and Sass (2012) assessed the potential for bias in fixed verses randomly selected sampling locations using LTEF AC electrofishing data. Their analysis indicates that continued sampling at the fixed locations could introduce spatial bias by collecting a higher number and greater diversity of fishes in "good" habitats than at randomly selected sites in habitats of mixed quality. If the LTEF program's primary goal is to provide descriptions of spatial and temporal trends in fish populations throughout the Illinois River Waterway, then monitoring at randomly selected locations, represented by an accurate depiction of available habitats, may provide a more reliable and defensible depiction of riverine fish communities.

Another concern for the continued maintenance of the $\mathrm{AC}$ electrofishing survey is the increased potential for fish injury or mortality when using $\mathrm{AC}$ electrofishing gears. In a review of fish injury studies, Snyder (2003) concluded that $\mathrm{AC}$ electrofishing gears were more harmful to fishes than the more regulated pulsed-DC gears. Incidences of internal hemorrhaging, asphyxiation, gill damage, and acute mortality were more common in studies in which AC gears were used to collect fishes (Snyder 2003). An increased awareness of fish welfare is becoming more widespread among biological researchers (Huntingford et al. 2006), and the adoption of less harmful fish 
collection methods should become an operational priority for INHS research programs.

\section{A transition in electrofishing sampling approaches}

The original fixed-site AC electrofishing program was the genesis of long-term surveys in the region, establishing a standard for sustained surveys to monitor quantitative trends in fishes. Additionally, the increasing difficulty of maintaining fixed sampling stations in habitats affected by anthropogenic and natural disturbances, such as sedimentation and island erosion, further reduces the benefits of the fixed-site surveys. Although there is unquestionable value in maintaining strictly standardized sampling regimes to facilitate comparisons over long periods, the logistical costs of maintaining historic operations outweigh the benefits of maintaining a separate $\mathrm{AC}$ electrofishing program in the Illinois Waterway. Moreover, the inherently dynamic nature of large rivers makes fixed-site monitoring less ideal than in less dynamic ecosystems (e.g., natural lakes; Schaeffer et al. 2005). Such considerations have prompted LTEF project managers to reevaluate the logic of continuing the historic $\mathrm{AC}$ survey and to consider a new redistribution of effort and resources to expanded LTRM-style random-site pulsedDC surveys throughout the state. Illinois River Biological Station scientists' recent analysis (D. Gibson-Reinemer et al., unpublished data) suggests that a full conversion to a random-site, pulsed-DC electrofishing survey would not hinder, and perhaps would even advance, the monitoring of riverine fish communities. Fixed-site AC electrofishing (LTEF) and random-site pulsed-DC (LTRM) protocols have been used concurrently in the La Grange Reach beginning in 1989, which allows for a side-by-side comparison of the two sampling designs. Because the programs have spatio-temporal overlap, we can compare the observed trends in sportfish species and evaluate which program provides higher precision, facilitating an earlier detection of trends (Figure 5). The uncertainty in trends from LTEF AC data is higher than in the LTRM pulsed-DC data, and the LTRM data show a greater ability to detect a decline in stock-sized sportfish than the AC data. One original goal of the $\mathrm{AC}$ electrofishing program was to provide information on the status of fish populations, and by this measure, the design of the LTRM element's pulsed-DC electrofishing is more effective at producing this information. The full-scale implementation of LTRM style pulsed-DC sampling methods throughout the Illinois Waterway and other rivers in Illinois can provide fisheries researchers and managers with more robust and reliable datasets with increased comparability among systems.

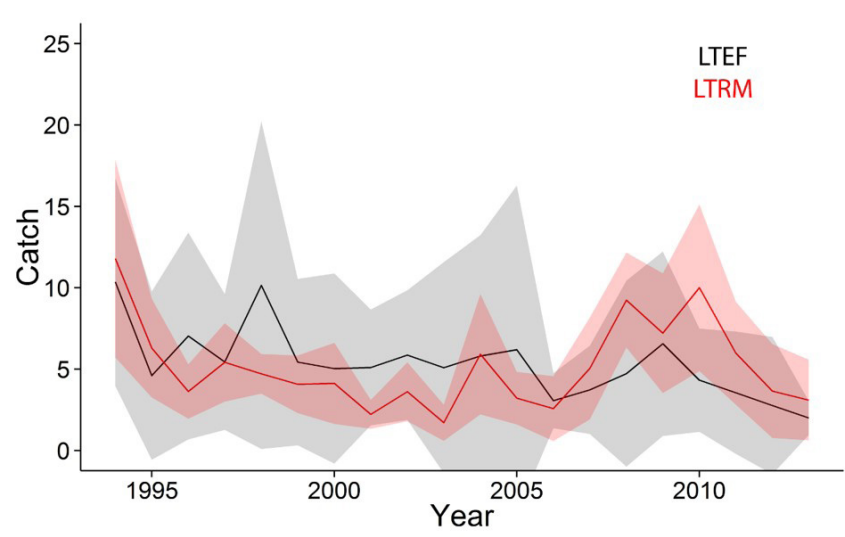

Figure 5. Comparison of trends between fixed-site AC electrofishing (LTEF) and random-site pulsed-DC (LTRM) protocols in the La Grange Reach of the Illinois River as a function of time from 1994 to 2013. Trend lines indicate mean catch of stock-size sportfish (per 15-minute period); shaded area is +/- SD. 


\section{CONCLUSIONS}

The LTEF is one of the first and most enduring long-term ecological assessment programs in North America, conducted annually with standardized sampling methodology and field protocols for over 50 years. Moreover, LTEF remains one of the very few organismal monitoring and assessment programs conducted in large floodplain rivers in North America on a decadal time scale. The LTEF has provided a wealth of insights into the structure and function of these important and multi-use ecosystems. These insights are important to both basic and applied research. For example, LTEF sampling and its biologists have produced foundational theories taught in many aquatic ecology textbooks, including the Flood Pulse Concept (Junk et al. 1989) and the Naturalized Flow Regime (Poff et al. 1997). In more applied arenas, the record of changing fish assemblages shows the effectiveness of national policies such as the Clean Water Act of 1972 on affecting change in severely degraded systems (McClelland et al. 2012). Additionally, LTEF products are among the earliest work on restoring floodplain rivers (Sparks et al. 1990; Sparks 1995). One important contribution of the program and its generations of staff is a clear demonstration of just how much can be learned and accomplished from high-quality datasets such as these.

Although adherence to the original standardized methodology has long been one of the strengths of LTEF, the interplay of new statistical tools and advanced field sampling designs have allowed more powerful and complex analyses. Other field assessment programs in the basin have demonstrated that they can complement and enhance LTEF's ability to generate insight into the structure and function of large river fisheries. To take advantage of these advances, and in recognition of the changing nature of threats to the river resource (decadal climate shifts and chronic sedimentation have largely replaced point-source pollution as the top threats), LTEF has been re-evaluated and will fully transition to a pulsed-DC methodology adapted from the LTRM during 2016. This marks an opportunity to increase the scope and quantitative power of an already strong tool for river management. Going forward, these changes will build on the program's past success and provide more information and understanding for managers, policy analysts, and scientists working on the next generation of management and restoration issues.

\section{MAJOR CONTRIBUTIONS OF THE LTEF PROGRAM}

In addition to the annual INHS technical reports, data generated from both the fixed-site $\mathrm{AC}$ and random-site DC surveys have been used to

- document large-scale changes in the structure of riverine fish communities (Sparks and Starrett 1975; Pegg and McClelland 2004; McClelland et al. 2012),

- estimate the effects of flow alterations on riverine fish communities (Koel and Sparks 2002; Yang et al. 2008),

- investigate the evolving role of nonnative species in Illinois' riverine ecosystems (Raibley et al. 1995; Irons et al. 2006, 2007, 2011; Sass et al. 2010; Liss et al. 2013, 2014; Lamer et al. 2014),

- evaluate the efficiency of electrofishing gears for large-river fisheries research (McClelland et al. 2012, 2013), and

- guide the development of ecological theory for large river ecology (Junk et al. 1989).

Given this impressive legacy of scientific research, the LTEF program can continue to provide high-quality data for important assessments of riverine fish populations in relation to contemporary environmental perturbation such as climate shifts, on-going loss of sidechannel and backwater habitats to sedimentation, unnatural water-level fluctuations from lock and dam operations, poor water quality, and river channel maintenance and dredging 
activities. The appendix of this bulletin offers a subject-oriented bibliography of the contributions of LTEF biologists to a broader understanding of ecosystem-based management, temporal and spatial patterns of fish community structure, invasive species ecology, response of fish communities to environmental remediation, and the calibration and conversion of different electrofishing gears in riverine environments. 


\section{LITERATURE CITED}

Bhowmik, N. G., and M. Demissie. 1989. Sedimentation in the Illinois River Valley and backwater lakes. Journal of Hydrology 105:187-195.

Burkhardt, R. W., and S. Gutreuter. 1995. Improving electrofishing catch consistency by standardizing power. North American Journal of Fisheries Management 15:375-381.

Burr, B. M., and L. M. Page. 2009. Illinois fish communities: More than a century of change. In Canaries in the catbird seat: The past, present, and future of biological resources in a changing environment. Ed. C. A. Taylor, J. B. Taft, and C. E. Warwick. Illinois Natural History Survey Special Publication 30, Champaign, IL.

DeBoer, J. A., M. W. Fritts, B. J. Lubinski, J. Parker, E. F. Culver, D. K. Gibson-Reinemer, J. E. Epifanio, J. H. Chick, Y. Cao, and A. F. Casper. 2015. The Long-Term Illinois Rivers Fish Population Monitoring Program 2014. Project F-101-R, Segment 26. Annual Report prepared for the Illinois Department of Natural Resources, Division of Fisheries and the U.S. Fish and Wildlife Service.

Forbes, A. A., and R. E. Richardson. 1913. Studies on the Biology of the Upper Illinois River. Illinois Natural History Survey Bulletin volume 9, number 10, Champaign, IL.

Gutreuter, S., R. Burkhardt, and K. Lubinski. 1995. Long-Term Resource Monitoring Program Procedures: Fish Monitoring. National Biological Service, Environmental Management Technical Center, Onalaska, WI. LTRMP 95-P002-1: 42 pp.

Havera, S. P., and F. C. Bellrose. 1984. The Illinois River: A lesson to be learned. Wetlands 4:29-41.

Huntingford, F. A., C. Adams, V. A. Braithwaite, S. Kadri, T. G. Pottinger, P. Sandøe, and J. F. Turnbull. 2006. Current issues in fish welfare. Journal of Fish Biology 68:332-372.
Irons, K. S., M. A. McClelland, and M. A. Pegg. 2006. Expansion of Round Goby in the Illinois Waterway. The American Midland Naturalist 156:198-200.

Irons, K. S., G. G. Sass, M. A. McClelland, and J. D. Stafford. 2007. Reduced condition factor of two native fish species coincident with invasion of non-native Asian carps in the Illinois River, USA: Evidence for competition and reduced fitness? Journal of Fish Biology 71 (Supplement D):258-273

Irons, K. S., G. G. Sass, M. A. McClelland, and T. M. O'Hara. 2011. Bigheaded carp invasion of the La Grange Reach of the Illinois River: Insights from the Long Term Resource Monitoring Program. Pages 31-50. Ed. D. C. Chapman, M. H. Hoff. In Asian carps in North America. American Fisheries Society Symposium 74. American Fisheries Society, Bethesda, MD.

Junk, W. J., P. B. Bayley, and R. E. Sparks. 1989. The flood pulse concept in river-floodplain systems. Canadian Journal of Fisheries and Aquatic Sciences 106:110-27.

Lamer, J. T., G. G. Sass., J. Q. Boone, Z. H. Arbieva, S. J. Green, and J. M. Epifanio. 2014. Restriction site-associated DNA sequencing generates high-quality single nucleotide polymorphisms for assessing hybridization between bighead and silver carp in the United States and China. Molecular Ecology Resources 14:79-86.

Liss, S. A., G. G. Sass, and C. D. Suski. 2013. Spatial and temporal influences on the physiological condition of invasive silver carp. Conservation Physiology 1: doi:10.1093/conphys/ $\cot 017$.

Liss, S. A., G. G. Sass, and C. D. Suski. 2014. Influence of local-scale abiotic and biotic factors on stress and nutrition in invasive silver carp. Hydrobiologia 736:1-15.

Koel, T. M., and R. E. Sparks. 2002. Historical patterns of river stage and fish communities as criteria for operations of dams on the Illinois River. River Research and Applications 18:3-19. 
McClelland, M. A., M. A. Pegg, and T. W. Spier. 2006. Longitudinal patterns of the Illinois Waterway fish community. Journal of Freshwater Ecology 21:91-99.

McClelland, M. A., and G. G. Sass. 2012. Assessing fish collections from random and fixed site sampling methods on the Illinois River. Journal of Freshwater Ecology 27:325-333.

McClelland, M. A., G. G. Sass, T. R. Cook, K. S. Irons, N. M. Michaels, T. M. O'Hara, and C. S. Smith. 2012. The Long-term Illinois River Fish Population Monitoring Program. Fisheries 37:340-350.

McClelland, M. A., K. S. Irons, G. G. Sass, T. M. O'Hara, and T. R. Cook. 2013. A comparison of two electrofishing methods used to monitor fish on the Illinois River, Illinois, USA. River Research and Applications 29:125-133.

Neumann, R. M., C. S. Guy, and D. W. Willis. 2012. Length, weight, and associated indices, pages 637-676. In Fisheries techniques, 3rd edition. Ed. A. V. Zale, D. L. Parrish, and T. M. Sutton.. American Fisheries Society, Bethesda, MD.

Parker, J., J. Epifanio, A. Casper, and Y. Cao. 2015. The effects of improved water quality on fish assemblages in a heavily modified large river system. River Research and Applications doi: 10.1002/rra.2917.

Pegg, M. A., and M. A. McClelland. 2004. Assessment of spatial and temporal fish community patterns in the Illinois River. Ecology of Freshwater Fish 13:125-135.

Poff, N. L., J. D. Allan, M. B. Bain, J. R. Karr, K. L. Prestegaard, B. D. Richter, R. E. Sparks, and J. C. Stromberg. 1997. The natural flow regime. BioScience 47:769-784.

Raibley, P. T., K. D. Blodgett, and R. E. Sparks. 1995. Evidence of grass carp (Ctenopharyngodon idella) reproduction in the Illinois and upper Mississippi Rivers. Journal of Freshwater Ecology 10:65-74.
Ratcliff, E. N., E. J. Gittinger, T. M. O'Hara, and B. S. Ickes. 2014. Long Term Resource Monitoring Program Procedures: Fish Monitoring. U.S. Army Corps of Engineers, Upper Mississippi River Restoration-Environmental Management Program, Report LTRMP-2014-P001, Rock Island, IL.

Sass, G. G., T. R. Cook, K. S. Irons, M. A. McClelland, N. N. Michaels, T. M. O'Hara, and M. R. Stroub. 2010. A mark-recapture population estimate for invasive silver carp (Hypophthalmichthys molitrix) in the La Grange Reach, Illinois River. Biological Invasions 12:433-436.

Schaeffer, J. S., A. Bowen, M. Thomas, J. R. P. French III, and G. L. Curtis. 2005. Invasion history, proliferation, and offshore diet of the round goby Neogobius melanostomus in western Lake Huron, USA. Journal of Great Lakes Research 31:414-425.

Snyder, D. E. 2003. Invited overview: Conclusions from a review of electrofishing and its harmful effects on fish. Reviews in Fish Biology and Fisheries 13:445-453.

Sparks, R. E., and W. C. Starrett. 1975. An Electrofishing Survey of the Illinois River, 19591974. Illinois Natural History Survey Bulletin volume 31, number 8, Champaign, IL.

Sparks, R. E., P. B. Bayley, S. L. Kohler, and L. L. Osborne. 1990. Disturbance and recovery of large floodplain rivers. Environmental Management 14:699-709.

Sparks, R. E. 1995. Value and need for ecosystem management of large rivers and their floodplains. Bioscience 45:168-182.

Starrett, W. C. 1971. Man and the Illinois River, 131-169. In River ecology and the impacts of man. Ed. R. T. Oglesby, C. A. Carlson, and J. A. Mccann. Academic Press, New York.

Yang, Y. C. E., X. Cai, and E. E. Herricks. 2008. Identification of hydrologic indicators related to fish diversity and abundance: A data mining approach for fish community analysis. Water Resources Research 44:W04412. 


\section{APPENDIX}

Select reports and peer-reviewed manuscripts derived from LTEF program data and personnel

\section{Bibliography of Illinois River ecological research including most LTEF project reports and publications}

Pegg, M. A. and S. P. Havera. 2001. Illinois River Natural Resources Bibliography: A Final Report to the U.S. Army Corps of Engineers-Rock Island District. Illinois Natural History Technical Report 2001-13 (available online, http://hdl. handle.net/2142/10250).

\section{Ecosystem-based Management}

Koel, T. M. 2000. Ecohydrology and Development of Ecological Criteria for Operation of Dams. Project Status Report 2000-02. U.S. Geological Survey, Upper Midwest Environmental Sciences Center, Onalaska, WI.

Koel, T. M. 2000. Abundance of Age-0 Fishes Correlated with Hydrologic Indicators. Project Status Report 2000-03. U.S. Geological Survey, Upper Midwest Environmental Sciences Center, Onalaska, WI.

Koel, T. M., and R. E. Sparks. 2002. Historical patterns of river stage and fish communities as criteria for operations of dams on the Illinois River. River Research and Applications 18:3-19.

Sparks, R. E. 1995. Value and need for ecosystem management of large rivers and their floodplains. Bioscience 45:168-182.

Sparks, R. E. 1995. Environmental effects, Pages 132-162. Ed. S. A. Changnon. In The great flood of 1993. University Corporation for Atmospheric Research (UCAR) and Westview Press.

Yang, Y. C. E., X. Cai, and E. E. Herricks. 2008. Identification of hydrologic indicators related to fish diversity and abundance: A data mining approach for fish community analysis. Water Resources Research 44:W04412.

\section{Temporal and Spatial Patterns of Fish Community Structure}

Lerczak, T. V., R. E. Sparks, and K. D. Blodgett. 1994. Some upstream-to-downstream differences in Illinois River fish communities. Transactions of the Illinois State Academy of Science 87(Supplement):53.

Lerczak, T. V., and R. E. Sparks. 1995. Fish populations in the Illinois River. Pages 7-9 in G.S. Farris, editor. Our living resources 1994. National Biological Survey, Washington, D.C.

Lerczak, T. V., R. E. Sparks, and K. D. Blodgett. 1995. Long-term trends (1959-1994) in fish populations of the Illinois River. Transactions of the Illinois State Academy of Science 88 (Supplement):74.

Lerczak, T. V. 1996. Illinois River Fish Communities: 1960's Versus 1990's. Illinois Natural History Survey Report No. 339, Champaign, IL.

McClelland, M. A., M. A. Pegg, and T. W. Spier. 2006. Longitudinal patterns of the Illinois Waterway fish community. Journal of Freshwater Ecology 21:91-99.

Pegg, M. A. and M. A. McClelland. 2004. Assessment of spatial and temporal fish community patterns in the Illinois River. Ecology of Freshwater Fish 13:125-135.

\section{Invasive Species Ecology}

Lamer, J. T., G. G. Sass, J. Q. Boone, Z. H. Arbieva, S. J. Green, and J. M. Epifanio. 2014. Restriction site-associated DNA sequencing generates high-quality single nucleotide polymorphisms for assessing hybridization between bighead and silver carp in the United States and China. Molecular Ecology Resources 14:79-86.

Liss, S. A., G. G. Sass, and C. D. Suski. 2013. Spatial and temporal influences on the physiological condition of invasive silver carp. Conservation Physiology 1: doi:10.1093/conphys/ $\cot 017$. 
Liss, S. A., G. G. Sass, and C. D. Suski. 2014. Influence of local-scale abiotic and biotic factors on stress and nutrition in invasive silver carp. Hydrobiologia 736:1-15.

Irons, K. S. M. A. McClelland, and M. A. Pegg. 2006. Expansion of round goby in the Illinois Waterway. The American Midland Naturalist 156:198-200.

Irons, K. S., G. G. Sass, M. A. McClelland, and J. D. Stafford. 2007. Reduced condition factor of two native fish species coincident with invasion of non-native Asian carps in the Illinois River, USA: Evidence for competition and reduced fitness? Journal of Fish Biology 71 (Supplement D):258-273.

Pegg, M. A. 2002. Invasion and transport of nonnative aquatic species in the Illinois River. Pages 203-209 in A.M. Strawn, editor. Proceedings of the 2001 Governor's conference on the management of the Illinois River System. Special Report Number 27, Illinois Water Resources Center, Champaign, IL.

Raibley, P. T., K. D. Blodgett, and R. E. Sparks. 1995. Evidence of grass carp (Ctenopharyngodon idella) reproduction in the Illinois and upper Mississippi Rivers. Journal of Freshwater Ecology 10:65-74.

Sass, G. G., T. R. Cook, K. S. Irons, M. A. McClelland, N. N. Michaels, T. M. O'Hara, and M. R. Stroub. 2010. A mark-recapture population estimate for invasive silver carp (Hypophthalmichthys molitrix) in the La Grange reach, Illinois River. Biological Invasions 12:433-436.

Tsehaye, I., M. Catalano, G. Sass, D. Glover, and B. Roth. 2013. Prospects for fishery-induced collapse of invasive Asian carp in the Illinois River. Fisheries 38:445-454.

\section{Response of Fish Communities to pollution}

Fritts, M. W., J. A. DeBoer, A. K. Fritts, K. A. Kellock, R. B. Bringolf, and A. F. Casper. 2016. Survey of intersex occurrence in Largemouth Bass (Micropterus salmoides) from the Upper
Illinois River Waterway. The American Midland Naturalist 176:158-165.

McClelland, M. A., G. G. Sass, T. R. Cook, K. S. Irons, N. M. Michaels, T. M. O'Hara, and C. S. Smith. 2012. The Long-term Illinois River Fish Population Monitoring Program. Fisheries 37:340-350.

Parker, J., J. Epifanio, A. Casper, and Y. Cao. 2015. The effects of improved water quality on fish assemblages in a heavily modified large river system. River Research and Applications doi: 10.1002/rra.2917.

\section{Gear Comparisons}

Gibson-Reinemer, D. K., D. R. Stewart, A. F. Casper, M. W. Fritts, and J. A. DeBoer. In press. Estimating the effects of environmental variables and gear type on the detection and occupancy of large river fishes in a standardized sampling program using multi-season Bayesian mixture models. North American Journal of Fisheries Management.

McClelland, M. A., K. S. Irons, G. G. Sass, T. M. O'Hara, and T. R. Cook. 2013. A comparison of two electrofishing methods used to monitor fish on the Illinois River, Illinois, USA. River Research and Applications 29:125-133.

McClelland, M. A and G. G. Sass. 2012. Assessing fish collections from random and fixed site sampling methods on the Illinois River. Journal of Freshwater Ecology 27:325-333.

\section{Assessment of Injury Rate to Sportfishes from Pulsed-DC Boat Electrofishing}

Culver, E. F., and J. H. Chick. 2015. Shocking results: Assessing the rates of fish injury from pulsed-DC electrofishing. North American Journal of Fisheries Management 35:1055-1063.

\section{Foundation for Important Theories in Aquatic Ecology and River Science (with $100+$ Citations Each)}

Junk W. J., P. B. Bayley, and R. E. Sparks. 1989. The flood pulse concept in river-floodplain 
systems. Canadian Journal of Fisheries and Aquatic Sciences 106:110-27.

Poff, N. L., J. D. Allan, M. B. Bain, J. R. Karr, K. L. Prestegaard, B. D. Richter, R. E. Sparks, and J. C. Stromberg. 1997. The natural flow regime. BioScience 47:769-784.

Sparks, R. E., P. B. Bayley, S. L. Kohler, and L. L. Osborne. 1990. Disturbance and recovery of large floodplain rivers. Environmental Management 14:699-709.

Sparks, R. E. 1995. Need for ecosystem management of large rivers and their floodplains. BioScience 45:168-182.

Sparks, R. E., J. C. Nelson, and Y. Yin. 1998. Naturalization of the flood regime in regulated rivers. BioScience 48:706-720.

Swanson, F. J., and R. E. Sparks. 1990. Longterm ecological research and the invisible place. BioScience 40:502-508. 
NOTES 

RESEARCH INSTITUTE

Illinois Natural History Survey Forbes Natural History Building 1816 South Oak Street Champaign, Illinois 61820 217-333-6880 